University of Nebraska - Lincoln

DigitalCommons@University of Nebraska - Lincoln

$11-1-2001$

\title{
The Hybrid Librarian: The Affinity of Collection Management with Technical Services and the Organizational Benefits of an Individualized Assignment
}

\author{
Gail Z. Eckwright \\ University of Idaho Library, gze@uidaho.edu \\ Mary K. Bolin \\ University of Nebraska--Lincoln, mbolin2@unl.edu
}

Follow this and additional works at: https://digitalcommons.unl.edu/libraryscience

Part of the Library and Information Science Commons

\footnotetext{
Eckwright, Gail Z. and Bolin, Mary K., "The Hybrid Librarian: The Affinity of Collection Management with Technical Services and the Organizational Benefits of an Individualized Assignment" (2001). Faculty Publications, UNL Libraries. 45.

https://digitalcommons.unl.edu/libraryscience/45
}

This Article is brought to you for free and open access by the Libraries at University of Nebraska-Lincoln at DigitalCommons@University of Nebraska - Lincoln. It has been accepted for inclusion in Faculty Publications, UNL Libraries by an authorized administrator of DigitalCommons@University of Nebraska - Lincoln. 


\title{
The Hybrid Librarian: The Affinity of Collection Management with Technical Services and the Organizational Benefits of an Individualized Assignment
}

\author{
by Gail Z. Eckwright and Mary K. Bolin
}

Collection management and technical services have a natural affinity that is not reflected in the organization of many academic libraries, where subject librarians are often aligned with reference. This article examines organizational and individual approaches to librarian assignment, along with the place of collection management in the organization.

L ibraries are organized to provide service. The division of functions is designed to acquire materials, provide intellectual access to them, house and circulate them, and assist library users in finding information. The assignment of responsibility to librarians follows this organizational pattern. Specialties, positions, and job descriptions generally reflect a functional or departmental orientation. Education for librarianship follows it as well. Librarians are educated to take up responsibility in one or more of the functional areas-reference, cataloging, acquisitions, and so on.

Although the roles of employees reflect this functional approach to organization, an individual may want something different, an assignment that does not reflect the division and alignment of services as depicted on the library's organizational chart. The result of that desire can be a kind of "hybrid," that is, the offspring of different varieties of an organism, something combined from elements that are different. Implicitly, a hybrid is something new and special, and it is something that makes the garden special as well.
To create a hybrid, the library must be able to look beyond the functional organization of services to a more collegial model that is not task-oriented or bureaucratic. This article looks at organizational and individual solutions to the assignment of responsibilities and presents a collegial model that benefits both the library and the individual.

This model is illustrated by the case of an individualized assignment for an academic librarian, one that was not a "reorganization" but which was an individual change that had an impact on the organization. The experience of one very successful "hybrid" librarian is set in the context of organizational and individual solutions, the nature of "assignment" for academic librarians, and the place of collection management and its relationship to other library functions.

\section{ORGANIZATIONAL AND INDIVIDUAL SOLUTIONS}

Library departments and specialties reflect the desire of librarians to acquire and organize material, assist patrons, and so on. Librarians are aware of these organizational patterns, and in their education for librarianship and in looking for employment, begin to define themselves according to one of these patterns, with an exclusive interest in one or more specialties or with an interest in a number of them or in some combination.

There are some common combinations of functions and specialties. The split between public and technical services is one between a group of specialties. Reference and instruction are traditional public services functions that are frequently found together, departmentally and in individual job descriptions. Collection management is generally a public services function, and, in many libraries, it is a responsibility assigned reference librarians. Technical services traditionally consist of acquisitions, cataloging, and serials control. These assignments may stand alone or be combined, organizationally or individually, that is, a serials-acquisitions department, a serials department that includes serials cataloging, or an individual with responsibilities for more than one of these functions. 
While there may be overlap and crossover between public and technical services, with catalog librarians serving on the reference desk or participating in instruction, for example, collection management can be part of public or technical services, or, indeed, may stand alone organizationally. It has affinity with acquisitions, because of the close relationship of selecting with searching, ordering, fund management, and so on. Collection management also has an affinity with reference, since library patrons are the ones who use the collection, and reference librarians know what people are looking for and what kinds of materials they need. Collection management also has an affinity with cataloging, though this is rarely seen organizationally. Selectors have subject knowledge and knowledge of the library collection that are useful for cataloging, as useful as the insight gathered by doing reference.

While it may be convenient for the organization to place library functions in departments and assign those functions to the librarians in the department, it is also possible to look at individuals first and assign them the functions that they are best at. A matrix organization attempts to do this by having a matrix of functions, with each librarian assigned one or more of them, creating virtual departments from this matrix of assignments. Individual assignment does not require the involvement of everyone in the organization or the creation of a matrix, team, or other organizational variant. It only requires a view of librarians that allows them to operate with autonomy, expertise, and a scholarly outlook, and not as drones with certain departmentallydetermined functions.

One variation of this individual assignment already exists in many libraries. It is considered quite normal and natural for a catalog librarian to want to spend time on the reference desk. The rationale seems obvious: to see first-hand how patrons use the catalog, to use expertise with bibliographic records to aid and instruct, and to provide some relief from the dull chore of cataloging. The last "benefit" is not always stated explicitly or in such frank terms, but this implicit view of cataloging is a persistent one. Many people have difficulty accepting the idea that anyone would voluntarily move from reference to cataloging, and the view that cataloging is a safe place to hide is as persistent as the idea that it is no fun. Historically, cataloging in particular has been seen as a place where an unproductive or marginal person can do the least harm.

\section{CHANGE}

Once a library has chosen a model of organization and has maintained it for some time, that model begins to seem natural, and the way responsibilities are assigned, the grouping together of certain functions, the way positions are filled and new librarians recruited, become a reflection of that model of organization. The library may decide to reorganize. Reorganization can imply many things, from dividing or consolidating functions to implementing an entirely new model (e.g., from a hierarchical departmental structure to self-managing teams). Whether a reorganization is done for budgetary or philosophical reasons, or both, its purpose is to deliver service by dividing the library's responsibilities among employees.

An individual can undergo a change in assignment in several ways. One is by taking on a different position (e.g., going from being a catalog librarian to being the head of cataloging, or from being a catalog librarian to being a reference librarian). This might happen because the individual wants a change or more responsibility. Reorganization might also result in a change for an individual.

Both of those situations are organizationally determined. A librarian who would like to try something new is limited to the choices offered by the organization: a vacant position here, a department head slot there. In the case of a reorganization, the library determines what is needed to provide service, and assigns those responsibilities to the appropriate people. A less common situation is one in which an individual wants a change that would also result in a change to the organization. This generally means the assignment of functions that are not organizationally aligned to one person. For example, if the reference and cataloging functions are in separate departments, then it is out-of-the-ordinary for a reference librarian to expect to be assigned cataloging responsibility. This individualized, hybrid assignment is not determined by the way the library is organized.

The impact on the organization of organizationally determined changes is clear. Either there is a neutral change such as a transfer, a positive change in the assignment of greater responsibility to someone who is seen as able to take it on, or, in the case of a reorganization, the improvement in service that was presumably the reason for reorganizing. For the individual, a reorganization, promotion, or transfer can all be positive, negative, or neutral.

For an individualized assignment, it might seem that the potential benefit would be for the individual only, with the organization only able to hope for a neutral outcome at best In fact, the creation of the hybrid also creates new and unexpected opportunities for collaboration, for the use of expertise, and for discovering affinities among functions that are not reflected in the functional organization.

\section{VEANER'S PARADIGM}

Some combination of the organizational and the individual approaches is obviously necessary, but the scholarly nature of academic librarianship is more compatible with an organization based on the strengths, needs, and contributions of individual librarians. This approach reflects Allen Veaner's view that academic librarianship is "programmatic," that is, like the programs offered by academic departments, and that, far from the conventional views of most discussions of library organization and librarians' responsibilities, "everything is assigned and nothing is assigned."1 In this collegial model, assignment is not the assignment of tasks, and, just as the faculty of the university are the university, the librarians are the library, without regard to functional assignment or traditional specialties.

\section{OTHER STUDIES}

The organization of academic libraries has been extensively explored in the literature of librarianship. Much of that literature deals with organizational solutions such as teams, job rotation, split assignments, flattened organizations and so on, seeking efficiency for the organization and job satisfaction for the employee. 
The collection edited by Christine E. Thompson $^{2}$ offers a number of views of the library organization from this perspective. Many of the articles in this volume take the organizational view of the public-technical services split. ${ }^{3}$ Others look at this division more from the point of view of the individual, seeing the organization as a group of librarians who are autonomous individuals, scholars, and faculty members. ${ }^{4}$

The last decade has seen many accounts of team organizations in academic libraries, which attempt to maximize communication, realign expertise in a more efficient way. and presumably give more job satisfaction to team members. ${ }^{5}$ The team solution is an organizational approach, which imposes a structure on existing employees to carry out the organizational mission, rather than constructing an organization based on how individuals can each take responsibility for that mission.

The literature on collection management tends to focus on philosophies and techniques of selection, certain types of material, and individual collections. Nevertheless, a body of literature examines the organization of collection management and its role in the library. ${ }^{6}$

\section{CASE STUDY}

The University of Idaho (UI) Library has a central reference department and a technical services department that includes cataloging, acquisitions, and serials. Technical services has five librarians - four catalog librarians and the department head, out of a total of about 20 librarians in the entire organization. Three subject librarians have primary responsibility for collection management in the humanities, social sciences, and science, and other librarians have responsibility for individual budgets within those areas under the guidance of the subject librarian. UI librarians have faculty rank and are on tenure track, with responsibility for librarianship, research, and service.

Several years ago, at the request of the incumbent, the position of $\mathrm{Hu}$ manities Librarian at the UI Library was transferred from the reference department to the technical services department. The incumbent was an experienced, highly-competent reference librarian who enjoyed public services and was an asset to the reference de- partment. Transferring to technical services would not be a safe place to retreat, in fact the transfer would require learning to catalog all over again for the first time since library school and joining a department that is proud of its high productivity, responsiveness, and lack of a backlog. Ordinarily, such a transfer would have been fairly routine, but for one "detail:" transferring not just an individual but also the position of Humanities Librarian, with collection management responsibility and budget authority for all humanities subjects. This was an opportunity to create a hybrid. The benefits to the library included: keeping an experienced and productive librarian on the faculty; retaining the collection management and budgetary expertise of the librarian; using the librarian's knowledge of catalog users in a catalog environment; creating an opening in the reference department, where applicants for openings generally outnumbered those found in catalog librarian pools; and continued use of the "'hybrid" librarian for library instruction in specialized humanities subjects.

While this transfer was not a routine one because of the organizational implications, the model of faculty status enjoyed by UI librarians makes it relatively easy to accomplish. Library faculty job descriptions are revised yearly, and follow the same formal as teaching faculty: percentages of responsibility devoted to the areas of librarianship, research, and service, which change each year, whether because research projects and committee assignments change, or because assignments in librarianship change. The elements of the "librarianship" assignment have almost a matrix quality, in which library functions are overlaid on a departmental organization that does not entirely match the functional areas: catalog librarians may have some collection management or reference responsibilities, department heads have a managerial component along with an assignment in an area such as reference or cataloging, and so on. Moreover, while there are department heads with authority over the functional areas, librarians do not have "supervisors," and the dean writes the performance evaluations for all librarians. The Humanities Librar- ian job description was revised to replace reference responsibility with cataloging, leaving "research," "service," and, indeed, much of "librarianship" unaffected. This "hybrid" can be seen as the logical outgrowth of this model of faculty status and the continuous revision of job descriptions.

Shortly after transferring to technical services, the Humanities Librarian assumed sole responsibility for a substantial classification project. The assignment involved the parts of the Library of Congress (LC) P classification schedule that relate to English, American and foreign languages and literature. The UI Library had historically assigned its own author numbers during the years when the P schedule was still being developed. This system of local author numbers had its origin in the years before shared cataloging. All materials with a $\mathrm{P}$ call number had been routed to a librarian to check the classification and assign a call number if necessary. There had been a desire for at least 10 years to undertake a project to conform to LC author numbers for literature and re-class those things that had local numbers. Every literature title that comes through the department is checked to make certain that the books are correctly classed. At the same time, books with locally-assigned author numbers that do not conform to LC are re-classed. Completing this project will ultimately streamline the cataloging workflow, and therefore it has an organizational benefit, but the project is particularly interesting because of its connection with humanities collection management. It is especially beneficial to the Humanities Librarian to see every book destined for the P classification, since the English language and literature budget absorbs a substantial part of the overall humanities budget. Moreover, the Humanities Librarian now sees daily how books fit into the collection, and can readily note over-collecting and as easily find the gaps in the collection. The classification specialist for the Ps is required to become far more intimately acquainted with the collection than a reference librarian. A subject librarian who resides in technical services can be immersed more completely in collection management through projects like this one. 
Having someone with the background and inclination to take on this reclassification project was a definite benefit for the library. This project led the Humanities Librarian to take on responsibility for all classification of books and other materials whose OCLC records lack a call number. This was an unplanned consequence of creating this hybrid position, and illustrates how affinities emerge and how those affinities can have a very practical benefit for the library: the facility that a subject librarian has for subject analysis is valuable to the cataloging workflow, where there are more books needing call numbers than those needing original cataloging.

The Humanities Librarian continues to maintain a connection with the reference department, primarily through participation in specialized library instruction and through the Research Assistance Program (RAP). The Humanities Librarian position description retains the instructional component for specialized humanities subjects. This is accomplished through collaboration with a reference librarian. The reference librarian uses instruction and instructional technology skills while the Humanities Librarian uses intimate knowledge of the library's collection. The Humanities Librarian does research and preparation for the class, while the reference librarian works with the students in the classroom. The students have the a advantage of getting the best instruction from a pair of knowledgeable librarians. As for the RAP program, librarians volunteer to work individually with students who request special research assistance. When the topic calls for expertise in the humanities, the Humanities Litertea is often called on to work with that student.

\section{THE VIEW FROM TECHNICAL SERVICES}

While this hybrid assignment is very successful and satisfying to the individual, it has a distinct organizational benefit as well. The organizational benefit of having cataloging librarians serve on the reference desk is that reference has a larger pool to draw on, and catalog librarians have generally described the benefit that they receive of seeing the catalog from the patron's point of view. The organizational benefit of having the Humanities Librarian in technical services, with responsibilities in cataloging, is the converse of this. The very interesting perspective and expertise that a subject librarian (and an experienced reference librarian) brings to cataloging and to the other parts of technical services includes a historical knowledge of the collection, the ability to prioritize materials needing attention, and subject expertise that is at once broad and specialized, leading to a distinct talent for classification.

This arrangement shows an affinity of cataloging and subject librarianship. ${ }^{7}$ While reference departments may find it natural, or at least convenient, to have reference librarians with subject assignments, it seems equally natural to have someone with authority over a large part of the collection and therefore skills and knowledge that are very beneficial to cataloging, as well as to acquisitions, serials, and so on.

There was little or no resistance to this change, inside or outside of technical services. The negative reactions were primarily confined to those with a more rigid view of the organization, who saw not a hybrid but a mongrel, not something grown and nurtured, nor even something serendipitous, but some accidental freak of nature.

\section{CONCLUSION}

While the transfer of a subject librarian position from reference to technical services was done to satisfy an individual desire for a new challenge, in accommodating the request the organization retained a productive library faculty member and simultaneously exemplified Veaner's view regarding the programmatic nature of academic librarianship. An academic library is a holistic institution, greater than the sum of its parts. The "hybrid librarian" is one small step toward the ideal, where "everything is assigned and nothing is assigned." Although other libraries may want to consider exploring the affinity of collection management with cataloging, this hybrid may not be applicable to other libraries in any literal way-libraries may choose whatever form of organization and assignment that suits them, and what works for one person or organization may be inappropriate for another. In another sense, however, that is exactly the point. Reorganization is not the only way to create change. Organizational productivity can also be improved when an individual can have an individualized assignment. What is good for one person can be good for the organization. The result can be the hybrid job that might be seen as the best of all worlds: a satisfying mixture of functional responsibilities, along with the independence and scholarship essential for every academic librarian.

\section{NOTES AND REFERENCES}

1. Allen B. Veaner, "Paradigm Lost, Paradigm Regained? A Persistent Personnel Issue in Academic Librarianship, II" College \& Research Libraries 55 (September 1994): 393.

2. Christine E. Thompson, ed. Integration in the Library Organization (Binghamton, NY: Haworth Press, 1999). For another view of collegial management see Steve McKinzie, "Twenty-five Years of Collegial Management: The Dickinson College Model of Revolving Leadership and Holistic Librarianship," Library Philosophy and Practice 2 (Spring 2000). Available: www.uidaho.edu/ mbolin/mckinzie.htm (accessed January 30, 2001).

3. Maria Anna Jankowska \& Nancy J. Young, "Blurred Lines, Clear Future: Personal Perspectives on the Reference and Cataloger Partnership," Journal of Library Administration 29(2) (1999): 7-22; David Garnes \& Susan P. Smith, "Shared Experience: Working in Partnership in a Team-Based Environment," Journal of Library Administration 29(2) (1999): 95-102: Margaret Ving. The Fate Dualism: Technical Services vs. Public Services," Journal of Library Administration 29(2) (1999): 23-28.

4. Christine DeZelar-Tiedman, "Perfect Fit: Tailoring Library Positions to Match Individual Skills," Journal of Library Administration 29(2) (1999): 29-40; Mary K. Bolin, "The Collegial Environment and the Functional Organization." Journal of Library Administration 29(2) (1999): 39-62.

5. See, for instance. Susan Grigg, "Integration or Coordination? Reorganization for Special Collections 
Programs," Journal of Academic Librarianship 26 (March 2000): 133-138; Laura Bender, “Team OrganizationLearning Organization: The University of Arizona Four Years into It," Information Outlook 1(9) (September 1997): 19-27; David Garnes, "Shared Experience: Working in Partnership in a Team-Based Environment," Journal of Library Administration 29(2) (1999): 95-101; Anita Schuneman \& Deborah A. Mohr, "Team Cataloging in Academic Libraries: An Exploratory Survey," Library Resources \& Technical Services 38 (July 1, 1994): 257-266; John Lubans Jr., "Lessons for Libraries from a Self-Managing Team: The Orpheus Chamber Orchestra Experience," Library Administration $\mathcal{E}$ Management
12 (Summer 1998): 142-149; Suzan McGinnis, "The Electronic Resources Group: Using the Cross-Functional Team Approach to the Challenge of Acquiring Electronic Resources," Library Acquisitions: Practice and Theory 22(3) (1998): 295-301: Kayle S. Butcher, "Decision Making in a Team Environment," Library Administration \& Management 11 (Fall 1997): 222-229.

6. See, for example, Sheila D. Creth, "The Organization of Collection Development: A Shift in the Organization Paradigm," Journal of Library Administration 14 (1991): 67-79; Carolyn Bucknall, “Organization of Collection Development and Management in Academic Libraries," Collection Building 3 (1989): 11-21;
John Tucker, "Challenges Confronting the Social Sciences and Humanities in University Research Libraries," Collection Management 16(2) (1992): 1-11; Donald G. Frank \& Christine Kollen, "Humanities and Social Sciences Librarians in the Science-Engineering Library: Utilization and Implications for Effective Collection Development and Reference Services," Science E Technology Libraries 9(3) (1993): 63-69; Daniel Zager, "Collection Development and Management," Notes 56 (March 2000): 567-574.

7. This affinity is interestingly described in Patrick Wilson, "Patrick Wilson: A Bibliographer among the Catalogers," Cataloging \& Classification Quarterly 25 (1998): 305-316. 